\title{
Europa und die Welt 2020. Entwicklungen und Tendenzen, Hrsg. Andreas Marchetti, Louis Clouet, Nomos Verlag, Ba- den-Baden 2011, ss. 310.
}

Tłem dzisiejszych debat o stanie integracji europejskiej, sposobach zwalczania skutków kryzysu ekonomicznego, modelu integracji europejskiej w najbliższych latach jest nie zawsze dostrzegana przez środki masowego przekazu, aczkolwiek ważna, podejmująca tę tematykę debata w ramach grupy refleksyjnej, która w ostatnim półroczy zintensyfikowała częstotliwość spotkań ${ }^{1}$. Według „Die Welt” regularnością charakteryzują się również spotkania w składzie: J. M. Barosso, J. C. Juncker, M. Draghi, H. Rompuy. Ich celem ma być przygotowanie planu instytucjonalnej reformy UE, który ma być gotowy na grudniowy (2012) szczyt Rady Europejskiej $^{2}$. Nie mniej ważnym impulsem do badań nad przyszłością UE, jej miejscu i roli w zmieniającej się rzeczywistości międzynarodowej są tezy wygłoszone przez Przewodniczącego Komisji Europejskiej podczas dorocznego orędzia o stanie UE. Omawiane zagadnienia są również przedmiotem zainteresowań zachodnioeuropejskich think-tanków, a głosy w dyskusji docierają do Polski za pośrednictwem prasy popularno-naukowej i codziennej ${ }^{3}$. Większość autorów przywołanych tekstów ze zrozumieniem odnosi się do zintensyfikowanych dyskusji o Europie nie tylko w perspektywie 2020 roku, ale również w po tej dacie.

Opisywane wątki w znacznie szerszej perspektywie są przedmiotem zainteresowania grupy badawczej pracującej pod kierunkiem Andreas Marchetti i Louis Clouet. Efektem prac jest publikacja książkowa pt. Europa und die Welt. Entwicklungen und Tendenzen, 2020, przygotowana przez wydawnictwo Nomos. Książka podzielona została na pięć części zatytułowanych: Wstęp, Uwarunkowania globalne i lad światowy, Geopolityczne polożenie Unii Europejskiej, Wewnętrzne uwarunkowania Unii Europejskiej, Perspektywy UE w roku 2020. Każdy z rozdziałów zawiera rzetelną analizę obecnego stanu prawnego omawianego zagadnienia, do których zaliczyć należy m.in. problem migracji, rynku pracy, rozszerzenia UE, zmian instytucjonalnych, relacji UE z Federacją Rosyjską, z Chińską Republiką Ludową, czy też z Paktem Północnoatlantyckim w ramach Wspólnej Polityki Bezpieczeństwa i Obrony. Autorzy wskazując horyzont czasowy do 2020 roku motywowali swoją decyzję kilkoma przesłankami. Po pierwsze w tej perspektywie należy patrzeć na rozwój gospodarczy UE dookreślony poprzez strategię Europa 2020, czy też Wieloletnie Ramy Finansowe UE, aktualnie negocjowane w trilogu Parlamentu Europejskiego, Komisji Europejskiej i Rady Unii Europejskiej. Po drugie, perspektywa 2020 roku, to dla Autorów czas wejścia w życie wszystkich przepisów Traktatu lizbońskiego i czas na monitorowanie skuteczności zastosowania nowej definicji większości kwalifikowanej w Radzie UE. Ponadto Autorzy zakładaja, że do roku 2020 ustabilizuje się sytuacja gospodarcza Europy i świata, i tym samym będzie do preludium do rozpoczęcia badań nie nad prognozowanym, lecz kształtującym się porządkiem międzynarodowym.

Ze względu na podjętą tematykę moją uwagę zwróciły artykuły autorstwa Susanne Nies, Zur Zukunft der Institutionen und Integration, Jared Sannicksen, Zur politischen Landschaft Europas 2020 .

1 Jest to nowa inicjatywa ministrów spraw zagranicznych niektórych państw członkowskich m.in. Polski, Niemiec, Hiszpanii, Królestwa Danii, Niderlandów i in. Jedno ze spotkań odbyło się w Warszawie we wrześniu br.

2 Por. A. Ettel, J. Hilderbrand, S. Jost, Der Geheimplan fuer ein neues Europa, „Die Welt”, 3.06.2012.

3 Np. wiosenny numer kwartalnika „Res Publica Nowa” zamieszcza debatę o stanie Europy, w której wzięli udzial J. Fischer, J. Habermas, M. Król, W. Przybylski, J. Rupnik; wśród zachodnioeuropejskich tytulów wymienię najważniejsze: „Svenska Dagblatet”, „Der Standard”, „Romana Libera", "The Times" - tytuly z 24.09 .2012 r. 
Pierwszy tekst nawiązuje do bardzo aktualnej dzisiaj tematyki przyszłości UE. Jakkolwiek wielu badaczy, publicystów może ulec pozornemu zmęczeniu wskazywaniem nowych wytycznych dla tej perspektywy badawczej. Nie można jej jednak zatracać chociażby analizując wpływ na integrację dzisiejszych decyzji w zakresie nowej dyscypliny fiskalnej, zawiązywanych przy tej okazji nowych porozumień międzyinstytucjonalnych, czy też koalicji państw lobbujących na rzecz korzystnych dla siebie rozwiązań bądź to przez biuro Przewodniczącego Rady Europejskiej, bądź też poprzez lobbing w Parlamencie Europejskim. W wielu punktach artykuł S. Nies nie jest odkrywezy. Opisuje bowiem już znaną nam rzeczywistość zmiany instytucjonalnej w TL, czy też jej wpływu na sposób rządzenia w UE. Jednakże analiza obecnych zapisów traktatowych, jak również wskazanie wytycznych do debaty o przyszłości UE (Raport Montiego; Strategia Europa 2020 oraz Strategia Europa 2030) pozwalają kreślić perspektywy na przyszłość. Punktami odniesienia są tutaj: przewodniczący Rady Europejskiej; nowa równowaga instytucjonalna do osiagnięcia między Parlamentem, Radą i Komisją Europejską, uprawnienia i rola wysokiego przedstawiciela ds. polityki zagranicznej i bezpieczeństwa, reforma ESDZ, czy też podniesienie znaczenia wzmocnionej współpracy. Autorka śmiało twierdzi, że w 2020 roku UE nadal pozostanie niezidentyfikowanym obiektem politycznym, ale znacznie bardziej upodobni się do państwa narodowego. Autorka wskazuje również na możliwy scenariusz dwóch prędkości. Niestety nie uszczegóławia tego jak rozumie dwie prędkości rozwoju UE, czy tak jak rozumiano to u progu lat 90 -tych XX wieku, czy też jako dwie prędkości nadające nową hierarchię członkostwa i wpływu na UE.

Bardziej interesujący tekst o politycznym krajobrazie Europy w 2020 roku poczyniła Jared Sonnicksen. Autorka tekstu w tonie uspokajającym często burzliwą debatę o UE przekonuje, że historia integracji europejskiej pokazuje, że jest to proces zarówno kroków wstecz, jak i postępów i sukcesów. Dzięki dynamice integracji europejskiej - pisze Sannicksen - i składającym się na nią uwarunkowań, w które wpisuje się spill over integracyjne wspólnoty europejskie stały się nie tylko sposobem na wieloletni pokój i bezpieczeństwo, ale również stały się ważnym środkiem do rozwiązania stających przed państwami europejskimi wyzwań i problemów. Sonnicksen patrząc na UE z perspektywy Traktatu lizbońskiego konstatuje, że finalite politic organizacji sui generis nadal pozostaje otwartą perspektywą badawczą. Modele takie jak: Europa obywateli, federacja europejska, Europa elit, Europa a la carte cechuje ambiwalencja i anarchiczność w sytuacji, gdy dochodzi do politycznych napięć, w efekcie których tak definiowane perspektywy są kontestowane. Punktem wyjścia do prognoz w artykule Sonnicksen jest analiza stałych i nowych podziałów w Europie. Autorka wyróżnia następujące: zwolenników i przeciwników integracji; lewica i prawica; duże i małe państwa; bogate i biedne państwa; nowa i stara Europa; neoliberalny i socjalny paradygmat; supranacjonalny i międzyrządowy i in. Na podstawie badań wskazuje następujące prognozy: w przyszłości na znaczeniu nabierze konflikt między zwolennikami a przeciwnikami integracji europejskiej ${ }^{4}$. Ponadto na sile może nabierać konflikt między dużymi a małymi państwami członkowskimi. Spór ten już dzisiaj kreśli nowe linie podziału w odniesieniu do kształtu wieloletniego budżetu UE, nabierze na sile w kontekście wejścia w życie nowego systemu decyzyjnego w RUE. Ten sam mechanizm konfliktu - przewiduje Autorka - znajdzie odzwierciedlenie w relacjach UE-15 - UE-12; bogate - biedne państwa członkowskie i in. W przekonaniu Sonnicksen w najbliższych latach UE będzie zmierzała w kierunku Europy projektów, która zamiast podejmowania kolejnych reform, zmian traktatowych będzie zmierzała w kierunku jeszcze bardziej kompromisowego charakteru poszczególnych polityk. Alternatywą dla tego scenariusza jest silna polityzacja, w efekcie której pojawią się nowe pola konfliktów

4 Trend ten może okazać się niebezpieczny dla UE. Jeśli konflikt ten będzie narastał, to wynik wyborów do Parlamentu Europejskiego w 2014 roku może wskazać duże poparcie dla partii eurosceptycznych, co przeloży się na znaczne wzmocnienie tych ugrupowań na krajowych scenach politycznych. 
i/lub reforma traktatowa sankcjonująca dzisiejsze reformy zacieśniające współpracę m.in. w gronie państw eurogrupy ${ }^{5}$.

Rekomendowana książka zawiera interesujący zbiór wielu punktów widzenia ukazujących UE jako jednego $\mathrm{z}$ wielu aktorów na arenie politycznych i gospodarczych stosunków międzynarodowych. Większością prezentowanych tez wpisuje się we wspólnotową narrację o UE. Autorzy mogą nie dostrzegać, że jednym $z$ efektów kryzysu jest powrót do propaństwowej narracji o Europie, w której wezwania do solidarności europejskiej nie zawsze są wystarczająco słyszalne. Nie zmienia to faktu, że wartością dodatnią książki jest jej interdyscyplinarność i dobrze dobrane instrumentarium badawcze oraz rzetelna analiza naukowa. Treść całej książi, jak i jej poszczególne rozdziały mogą posłużyć do przygotowania dobrej kwerendy na potrzeby pracy magisterskiej, lub też mogą stanowić materiał źródłowy na seminarium naukowe poświęcone przyszłości UE.

MIKOŁAJ J. TOMASZYK

\section{Polityka zagraniczna. Aktorzy - potencjaly - strategie, red. Teresa Loś-Nowak, Wydawnictwo Poltext, Warszawa 2011, ss. 575.}

Stephen M. Walt, badacz stosunków międzynarodowych uznawany za przedstawiciela szkoły neorealistycznej, w jednym ze swoich często cytowanych artykułó ${ }^{1}{ }^{1}$ zapytuje, dlaczego osoby odpowiedzialne za tworzenie podstaw polityki zagranicznej oraz jej praktycy powinni zwracać uwagę na studia poświęcone tej problematyce. Szukając odpowiedzi, zauważa on, że istnieje silna więź łącząca świat teorii i ontologii. Teoria to „okulary”, przez które patrzymy na otaczający nas świat. Pozwala ona politykom wyselekcjonować z „lawiny informacyjnej” najistotniejsze wiadomości, dzięki czemu mogą oni podejmować właściwe decyzje polityczne. Jednocześnie teoretycy, odpowiedzialni za koncepcyjne ukształtowanie podstaw polityki zagranicznej, nie są w stanie tego dokonać bez odpowiedniej znajomości szeregu procesów i zjawisk zachodzących w realnym, otaczającym ich świecie.

Zagadnienie przedstawienia teoretyeznych i ontologicznych podstaw polityki zagranicznej poszczególnych państw, przy uwzględnieniu dryfu w systemie międzynarodowym w kierunku podmiotów nieterytorialnych, podejmuje Teresa Łoś-Nowak w dziele Polityka zagraniczna. Aktorzy - potencjaty - strategie. Wraz z grupą badaczy wywodzących się z rozmaitych ośrodków akademickich, m.in. z Wrocławia, Warszawy, Torunia, Olsztyna, Lublina i Gdańska prezentuje ona śmiałą i oryginalną wizję odejścia od schematycznego opisywania systemu międzynarodowego wyznaczanego przez metafore „Westfalii” jako hipotezy genezy w nauce o stosunkach międzynarodowych ${ }^{2}$. Wychodząc poza „granice” wyznaczone państwowocentryczną wizją stosunków międzynarodowych, zauważa: ,... z teoretycznego punktu widzenia jest jasne, że polity-

5 Jest to również jedna z konkluzji spotkania Grupy Refleksji w Palmie na Majorce. Gospodarz spotkania min. J. M. G. Margallo przypomnial, że nadszedł czas na odnowę UE i ma nadzieję na lepszy efekt niż miało to miejsce w Maastricht czy w Rzymie. Nadszedł czas na powstanie rządu gospodarczego Europy, który będzie bronił i państw, i wspólnej waluty. UE zdaniem Margallo powinna dążyć do bezpośrednich wyborów przewodniczącego KE. EurActiv z dnia 23.07.2012 r.

S. M. Walt, International Relations: One World, Many Theories, „Foreign Policy”, No. 110, Special Edition: Frontiers of Knowledge (Spring, 1998), s. $29-46$.

2 A. Gałganek, ,, Westfalia” jako hipoteza genezy w nauce o stosunkach międzynarodowych, w: Późnowestfalski lad międzynarodowy, red. M. Pietraś, K. Marzęda, Lublin 2008, s. 23. 